Scholedge International Journal of

Management \& Development

ISSN 2394-3378, Vol.05, Issue 12

Pg 132-140.

DOI: http://dx.doi.org/10.19085/sijmd051201
Published by: Scholedge Publishing www.theSCHOLEDGE.org

Email: editorial@thescholedge.org

CPublisher

\title{
Assessment of Pre-Service 'Teachers' Turnover Intentions in Relation to the Achievement of Sustainable Development Goals through Teacher Preparation in Southwestern Nigeria
}

\author{
OYETORO Oyebode Stephen ${ }^{1}$ \\ ${ }^{1}$ Department of Arts and Social Science Education, \\ Faculty of Education Obafemi Awolowo University, Ile-Ife, Nigeria.
}

\author{
ADESINA Bosede Abimbola $\mathrm{PhD}^{2}$ \\ ${ }^{2}$ Department of Arts and Social Science Education, \\ Faculty of Education Obafemi Awolowo University, Ile-Ife, Nigeria.
}

SALAWUDEEN Mujidat Olabisi ${ }^{3}$

${ }^{3}$ School of Arts and Social Science Education,

Osun State College of Education, Osun State, Nigeria.

\begin{abstract}
The study which was extracted from a larger study on the predictors of teaching efficacy of pre-service teachers (PRESETs) considered the implications of PRESETs' turnover intentions in the quest to achieve Sustainable Development Goals (SDGs) through teacher preparation. The paper argued that discussions and directions on using teacher education to achieve SDGs agenda by 2030 in Nigeria should prima facie establish that a significant number of teacher candidates would be motivated to stay in the teaching profession. The study utilized a descriptive survey research design. The sample comprised four hundred and four PRESETs who were selected using purposive sampling technique. Results showed that for every 400 teacher trainee candidates only about $29 \%$ are likely to end up in the teaching profession other things remaining the same. The implications of the present study for the achievement of the SDGs are also discussed.
\end{abstract}

Keywords: Pre-Service teachers; Sustainable Development Goals (SDGs); Turnover intentions; Accidental teacher education candidates; teaching profession

Article Classification: Research Paper 


\section{Introduction}

Different dialogues and postulations are being made on the alternative courses of action that would lead to the speedy realization of the presently instituted 17 Sustainable Development Goals (SDGs). These SDGs include: no poverty; zero hunger; good health and well-being; quality education; gender equality; clean water and sanitation; affordable and clean energy; decent work and economic growth; industry, innovation and infrastructure; reduced inequalities; sustainable cities and communities; responsible consumption and production; climate action; life below water; life on land; peace, justice and strong institutions; and partnership for the goals. These goals have been described as universal, transformational and inclusive and describe major development challenges for humanity (UNESCO, 2017). In recognition of the exigencies of achieving these universals and the complexities of achieving same, international organisations and agencies such as the Institute for International Education and Planning (IIEP) suggested going beyond the obvious and calls for debates on new ideas and strategies that will ultimately redefine the goals most especially those relating to quality education with the intended outcome of learning while ensuring accessibility for all.

Distinctively, education has been singled out as a viable means of achieving the other SDGs (UNESCO, 2017). Hence, education has been perceived as capable of helping individuals develop competencies that empower them to reflect on their own actions, taking into account their current and future social, cultural economic and environmental impacts from a local and global perspective. Education for Sustainable Development (ESD) is thus expected to empower individuals to act in complex situations in a sustainable manner, which may require them to strike out in new directions; and to participate in socio-political processes, moving their societies toward sustainable development (UNESCO, 2017). Yet, it is known that the success of education as a distinct field in helping to realise SDGs in spite of the ubiquity of technology is directly dependent on the quantity as well as the quality of teachers as it is not known if robots and artificial intelligence can completely take over the work of teachers. In essence, the most profound assumption of ESD could be conjectured to be the sufficiency of teachers who would drive the process of influencing the decisions of people towards committing themselves to the accomplishment of the SDGs through formal, informal and non-formal education.

As a fallout of the importance of teacher education in the provision of qualitative and quantitative education that would help realise the instituted SDGs, different layouts are made on how to improve on the model(s) of teacher education as obtained in various countries. The highpoints of these layouts include copious use of insights from the teacher education systems of developed and successful education systems such as Finland, Singapore, United States of America, Canada, Japan, etc. Hence, it could be expected that the quest for improving the quality and quantity of the preparations made for teachers would include and involve teacher education program- innovation, enrichment, expansion, reduction via specialization, etc. The considerations for these pathways in improving the quality of teachers for educational systems are indeed commendable. Yet, it may be imperative that stakeholders in teacher education most especially in developing countries such as Nigeria pause and reflect on the emerging fact that the success of any postulation and conjecture on improving teacher education programs would be based on teacher education candidates who are $a b$ initio motivated and willing to: enter the teacher education programs; stay and graduate in the programs; and are also willing to enter and stay in the teaching profession. All with the intent of transforming the teaching and learning processes presently obtained in the recognized levels of education viz.: early childhood, primary, secondary and higher education levels and in the forms of education which are technical and vocational education and training, adult education and life-long education, migrant and nomadic education among others towards improved and sustained development via education. Consideration of these later issues lie in studies on turnover intentions. This study is part of a larger study on the determinants of teaching efficacy of pre-service teachers in Osun state, Southwestern Nigeria.

\section{Shortage of teachers}

One of the problems that have plagued developmental efforts in Nigeria's educational system is the shortage of teachers in quantity and quality (Ehindero, 1994; Ehindero, 2014; Federal Ministry of Education, 1992; Obanya, 2014; Ukeje \& Aisiku, 1982). From the 1950s when the Universal Primary Education was initiated to the present, the story has not changed. The shortage is not limited to the basic education level only but to other levels (Federal Ministry of Education, 2016; Alabi \& Ige, 2014). Yet, many scholars in the field of education and the nation's policy on education continue to find recourse to the instrumentality of adequacy of teachers in the implementation of 
educational (and even developmental) policies, plans and programmes (Federal Republic of Nigeria(FRN), 2004; FRN/ILO, 2005; Odia \& Omofonmwan, 2007; Alabi \& Ige, 2014; Unterhalter, Ezegwu, Shercliff, Heslop \& North, 2015). In all sense of fairness to the Nigerian situation, the shortage of teachers appears to know no boundary of the level of socio-economic development as developed counties and countries have reported evidence of this dilemma (American Association of Colleges for Teacher Education (AACTE), 2010; Goldhaber, 2015). The peculiarities of Nigeria, however, leaves much to be desired as to how long it will take to put the right structures in place for the adequacy of teacher supply vis-à-vis demands in public and private schools; and formal, informal and non-formal educational settings in order to meet regular national educational programmes objectives and such other global developmental initiatives such as SDGs. The authors are quite aware of the emergence of the deployment of National Youth Service Corps (NYSC) members in secondary schools in order to augment shortfall in teacher supply and for the implementation of strategic developmental projects as with the HIV/AIDS and Millennium Development Goals (MDGs) awareness programmes. These corps members are often thought to be ubiquitous, youthful, willing to learn and flexible and capable of providing required feedbacks on instituted programmes as and when due. The question that calls for an answer at the moment is that: will the use of corps members be sufficient and efficient for the attainment of goals that should be sustained over time? Only time may tell.

\section{Accidental teacher education candidates}

The accidental teacher is a term used to refer to persons who: do not set out to become teachers; may or may not have a college degree in teacher education but ended up starting/building a relatively tenured career as teachers. Many accidental teachers are lured to become teachers by dint of the unavailability of desired jobs. Yet, many accidental teachers have been motivated to become exceptional teachers either by the nature of the extrinsic or intrinsic motivation they received and/or developed on the job while others have remained mediocres with farreaching negative implications on the outcomes of their students. A classic example of the former is a reflective autobiography provided by Tomlinson (2010). She mentioned five foundational elements and practices that make up the architecture of effective teaching. These are: finding a place that fits one; understanding teaching as a calling; knowing one does not know; associating oneself with quality; and generating one's own energy. The unpopularity of the teaching profession has been adduced to issues bordering on teacher quality and professionalism, promotion, discipline, remuneration, and working conditions (FRN/ILO, 2005).

Accidental teacher education candidates, on the other hand, capture adequately high school graduates who do not want to become teachers but on the conditions of either not having the requisite qualifications for other socially desirable courses or the exhaustion of available admission spaces by significant others found themselves in teacher education programs. As with the case of accidental teachers many accidental teacher education candidates have been motivated to really stay with the teacher education programs while some in spite of the closeness of the teacher education programs they were offered yet proceed to change their courses as possible. It is reasonably expected that a significant proportion of these ill-motivated teacher education candidates will eventually finish their programs and will yet take up teaching appointments. Suffice it to mention that teaching practice has been identified as one of the elements in teacher education programs that are capable of making accidental teacher candidates positively predisposed towards teaching though findings of research have shown conflicting results vis-à-vis this conjecture. For instance, Adeleke, Adesina, Salami, and Adebayo (2011) established that: the attitude of accidental candidates to lesson preparation improved after teaching practice; the interest of the students in teaching did not improve even after the exercise, and their opinion after lesson delivery improved after the teaching practice exercise. Zhao and Zhang (2017) also provided evidence of the influence of teaching practice on teachers' professional identity and commitment.

Accidental teachers and teacher education candidates have implications for studies on attrition and turnover intentions of teachers with consequent effect on teacher supply.

\section{Turnover intentions of in-service and pre-service teachers}

One of the challenges facing education systems the world over is teacher shortages caused by teachers who are leaving the job. Ingersoll (2002) reported that many teachers are reportedly leaving the profession for greener pastures. While turnover intentions otherwise known as attrition rates are low in some countries with highperformance indices such as the United States of America and Singapore (Darling-Hammond, Burns, Campbell, Goodwin \& Ling Low, n.d), developing economies have been reported to have a high turnover rate (Xaba, 2003). 
In a study on the demographic analysis of turnover intentions amongst Nigerian high school teachers, Ajayi and Olatunji (2017) found a significant correlation between teachers' intention to quit, and teachers' age, qualification, work status and experience. Teachers aged 36-45 years are least willing to quit. Teachers aged 55 years and above, and those aged below 35 years are most willing to quit. Insight drawn from this study was that managers need to target employees within the age brackets that are most willing to stay on and to work out appropriate strategies to retain those who are most valuable to the goals of the UBE and the organizations in which they serve. The implication of the study by Adeleke, Adesina, Salami, and Adebayo (2011) which reported that the interest of the students in teaching did not improve even after teaching exercise is that these pre-service teachers may leave the teaching profession even after securing employment as teachers. Factors associated with turnover intentions among newly qualified teachers include but are not limited to: lack of relational trust between teachers and teacherprincipal trust, role conflict, and lack of affective commitment to the teaching profession (Tiplic, Lejonberg \& Elstad, 2016). The high turnover rate of teachers thus brings to fore the need for all stakeholders chief of which is the government to give consideration to the need for concerted efforts to mobilize and harness the potentials of the (teaching) labor force (Matthew, Adediran, Adeleye \& Adegboye, 2017).

\section{Methods}

The study employed a survey research design. The population consists of pre-service teachers in teacher training institutions who observed their practice teaching in government-owned secondary schools in Ile-Ife, Ilesha, Ipetumodu, Modakeke, Osogbo and Ila-Orangun areas of Osun state during the 2015/2016 academic session. The sample comprised 404 teacher trainees who were selected using the purposive sampling technique. A questionnaire titled "Pre-service Teachers' Turnover Intention Questionnaire" (PTTIQ) that contains two major items on the intention to change from education programs to other programs and intention to start a career in teaching was utilized for the study. The two items are: "If I have my way, I would most likely change my present course of study to another course in other Faculties/Departments/Colleges" and "When I finish my B.A. Ed./B.Sc. Ed./B. Ed./NCE/PGDE program, I am most likely not going to take up a teaching job/assignment". The items were judged by experts in curriculum studies and tests and measurements to be valid for gathering information on the subject of interest. Data were analyzed using descriptive statistics of percentages and frequency counts.

\section{Results and Discussion of findings}

The responses of the PRESETs to the first item which stated that "If I have my way, I would most likely change my present course of study to another course in other Faculties/Departments/Colleges" were collated using frequency counts and percentages. The results obtained are as highlighted in Table 1.

Table 1: Table depicting respondents' intention to change their courses from teacher education courses to other courses

\begin{tabular}{rrrr}
$\begin{array}{l}\text { Response } \\
\text { Categories }\end{array}$ & Frequency & Percent & \multicolumn{2}{c}{$\begin{array}{c}\text { Cumulative } \\
\text { Percent }\end{array}$} \\
\hline Yes & 79 & 20.31 & 20.31 \\
\hline No & 310 & 79.69 & 100.0 \\
\hline Total & 389 & 100.0 &
\end{tabular}

Table 1 reveals that 79 responses out of total valid responses of 389 representing $20.31 \%$ would like to change their present course of study in Teacher Education to other courses in non-teacher education while 310 representing $79.69 \%$ would not want to study other courses. The information in Table 1 is further depicted by a bar chart in Figure 1. The margin between those who want to change from teacher education programs and those who would rather remain on the program though highly commendable should yet raise a lot of concerns for teacher educators. As insiders who have been involved as teacher education student advisors for an average of 10 years, students are often advised against changing their courses to non-teacher education programs as such changes are rarely approved by teacher education departments. Reasons for this include that a portion of fund/subventions to these departments are based on the number of students in them and that the receiving departments would have reached their limits for students' admissions. Suffice it to state that some of these changes include students who want to change from teacher education programs such as Education/Economics to Social Sciences Economics. Students who have their request for change in program approved would indeed have known high net-worth academics and university 
administrators who would sponsor such change. The raison d'etre is that if restrictions are not placed on these transfers from teacher education programs, one would wonder if there will be candidates for them. Teacher education is, therefore, a forced choice on most teacher education candidates who have been promised of change in their programs once they are admitted.

The low change-non change ratio could also be explained in terms of the universalization of degrees and commonalisation of skills expected of graduates of higher education (including teacher preparation institutions) programs in the global space. Hence, teacher education candidates could have been aware of the fact that the degree specialization does not matter in terms of general employment; what matters is the skills possessed such skills include: Learning and innovation skills (critical thinking and problem solving, communication, collaboration, creativity and innovation), information, media and technology skills (information literacy, media literacy, information, communications and technology literacy), life and career skills (flexibility and adaptability, initiative and self-direction, social and cross-cultural skills, productivity and accountability, leadership and responsibility) (American Association of Colleges of Teacher Education (AACTE), 2010). Other skills include entrepreneurship, numerical appreciation, and analytical skills and critical awareness. Also, there is the growing awareness and acceptance of degree qualifications irrespective of discipline as a basic entry requirement for professional examinations. Though the journey appears long, the ratio may also be adduced to the efforts of the Teachers' Registration Council of Nigeria (TRCN) towards professionalizing the teaching profession.

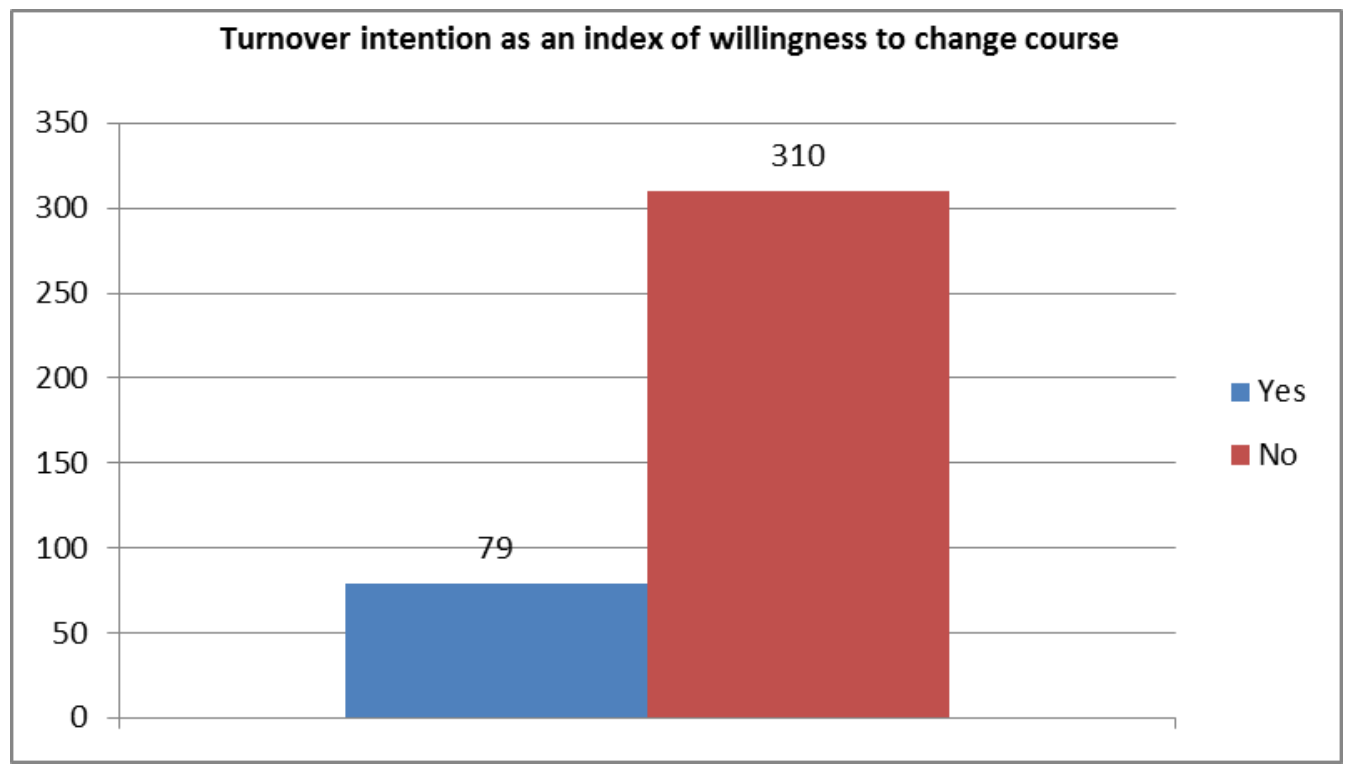

Figure 1: Chart showing respondents' intention to change their courses from teacher education courses to other courses

The second item in the questionnaire determined pre-service teachers' willingness to take up a teaching job at the completion of their teacher education programs. The respondents on a modified Likert-type scale of strongly disagree, disagree, moderately disagree, moderately agree, agree and strongly agree responded to the statement: "When I finish my B.A. Ed./B.SC. Ed./B. Ed./NCE/PGDE program, I am most likely not going to take up a teaching job/assignment". 
Table 2: Table showing pre-service teachers' willingness to take up other job asides teaching

\begin{tabular}{lrrr} 
Response Categories & Frequency & Percent & $\begin{array}{c}\text { Cumulative } \\
\text { Percent }\end{array}$ \\
\hline Strongly Disagree & 50 & 15.63 & 15.63 \\
\hline Disagree & 15 & 4.69 & 20.32 \\
\hline Moderately Disagree & 50 & 15.63 & 35.95 \\
\hline Moderately Agree & 80 & 25.0 & 60.95 \\
\hline Agree & 49 & 15.31 & 76.26 \\
\hline Strongly Agree & 76 & 23.74 & 100.0 \\
\hline Total & 320 & 100.0 &
\end{tabular}

Results obtained as displayed in Table 2 revealed that 50 out of the valid responses of 320 representing $15.63 \%$ stated that they strongly disagree to this statement, 15 pre-service teachers representing $4.69 \%$ disagree with this statement while yet another 50 representing $15.63 \%$ of the pre-service teachers moderately disagree with the statement. Since the statement is a negatively worded one, the implication is that these respondents that disagree with the statement in various extents are the ones who will most likely take up a teaching job/assignment after exiting their teacher education programs. On the other hand, 80 pre-service teachers representing $25 \%$ of the respondents moderately agree with the statement, 49 representing $15.31 \%$ agree with it while 76 of the respondents representing $23.74 \%$ strongly agree with the statement that on completion of their teacher education program, they are most likely not going to take up a teaching job/assignment. These results are further represented on a bar chart and are as shown in Figure 2.

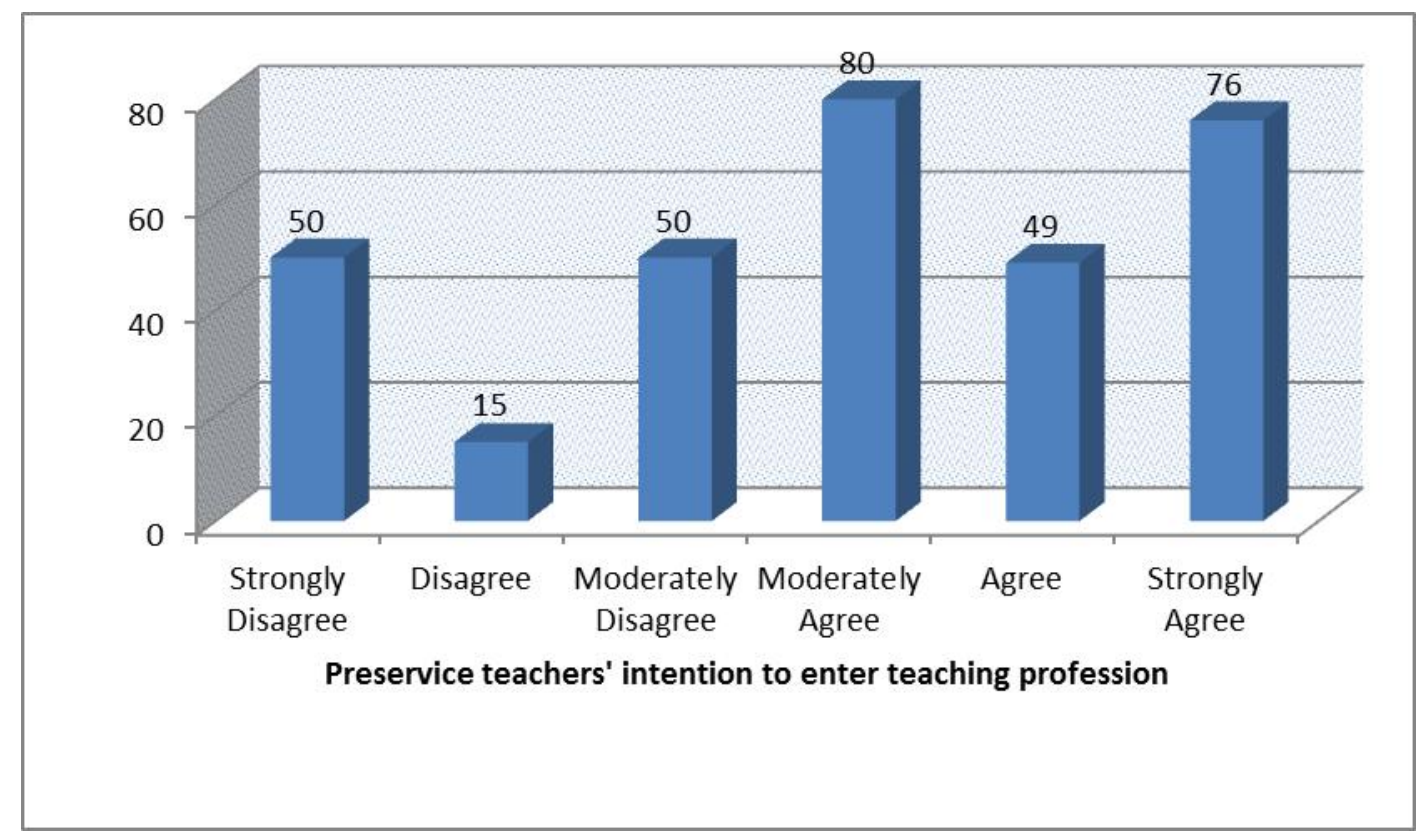

Figure 2: Chart showing pre-service teachers' intention to enter other jobs asides teaching

The extents of disagreement and agreement to the statement were further binned to have a unique figure for disagreement and agreement respectively. The result obtained is as displayed in Table 3. 
Table 3: Table showing binned responses of pre-service teachers' willingness to take up other job asides teaching

\begin{tabular}{lrrr} 
Response Categories & Frequency & Percent & $\begin{array}{c}\text { Cumulative } \\
\text { Percent }\end{array}$ \\
\hline Disagree & 115 & 35.94 & 35.94 \\
\hline Agree & 205 & 64.06 & 100.0 \\
\hline Total & 320 & 100 &
\end{tabular}

Table 3, shows that 115 representing 35.94 percent of the pre-service teachers polled disagreed with the statement that they are most likely not going to take up a teaching job/assignment after graduation from their teacher education program while 205 representing $64.06 \%$ agree to this statement. The result in Table 3 is further represented on a bar chart in Figure 3.

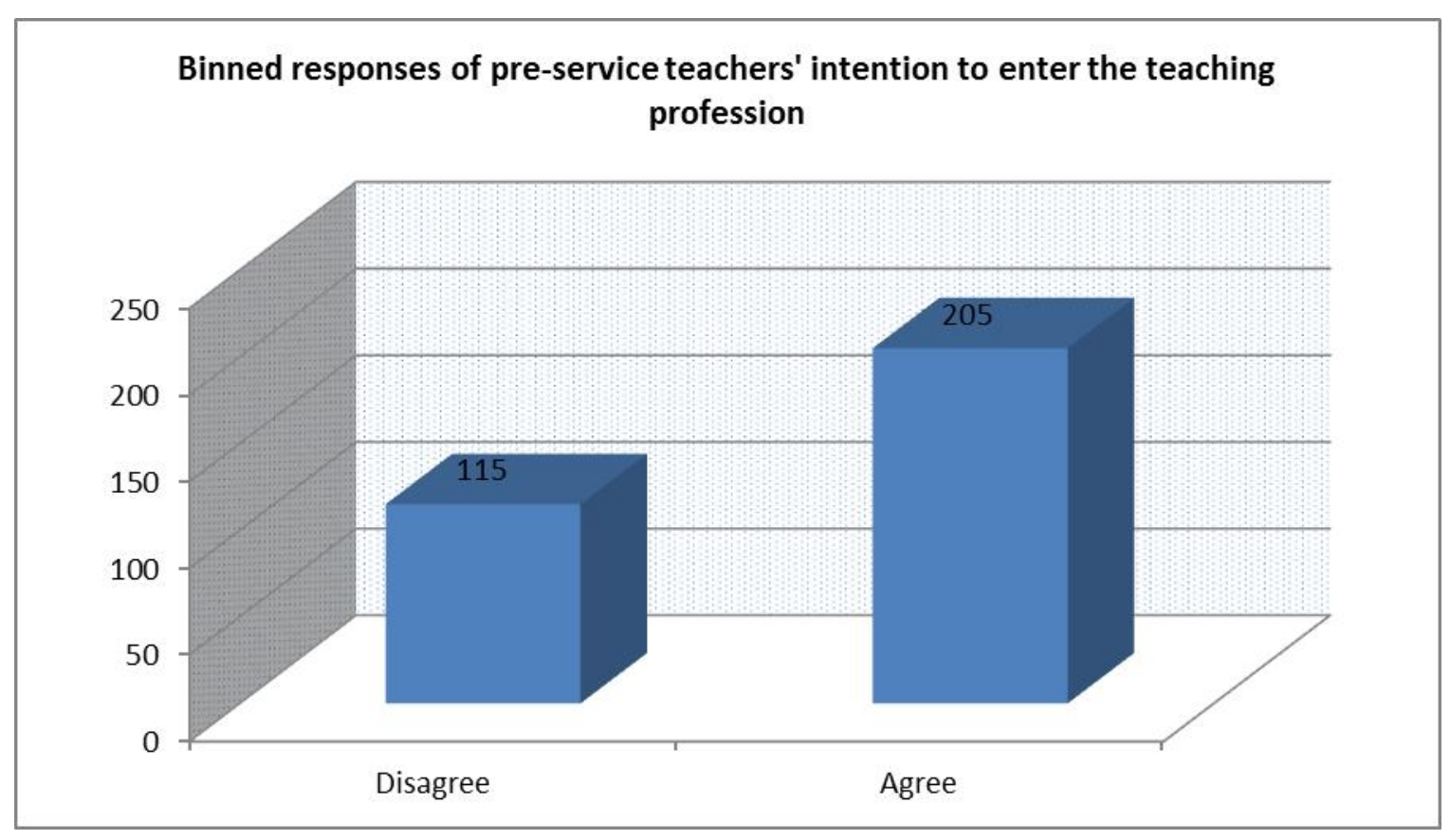

Figure 3: Chart showing binned responses of pre-service teachers' intention to enter other jobs asides teaching

The present findings are in dissonance with the findings on the analysis of item 1 where a significant number of teacher education candidates are willing to stay with teacher education programs till completion. It would have been expected that a high willingness to complete teacher education programs will be supported with a high willingness to enter the teaching profession. The present findings are not surprising in the light of the findings of Adeleke et al (2011) where it was reported that attitude of PRESETs to the teaching profession did not significantly improve after the teaching practice; such other evidence on high teacher turnover intentions (Tiplic, Lejonberg \& Elstad, 2016; Waititu, 2013; Unterhalter, Jegede, Ezegwu, North \& Shercliff, 2016); the pervasive evidence of low-income potential and growing wage gap compared to other skilled workers (Nolan, 2016).

Further analysis was done in order to obtain the composite score of the pre-service teachers who will enter the teaching profession. The score was computed as indicated below:

Calculation of composite preservice teachers' retention in teaching percentage $=$ Percentage of those who are not willing to change course* Percentage of those who disagree that they most likely will not take up other jobs asides teaching

$79.69 * 35.94=28.64$ 


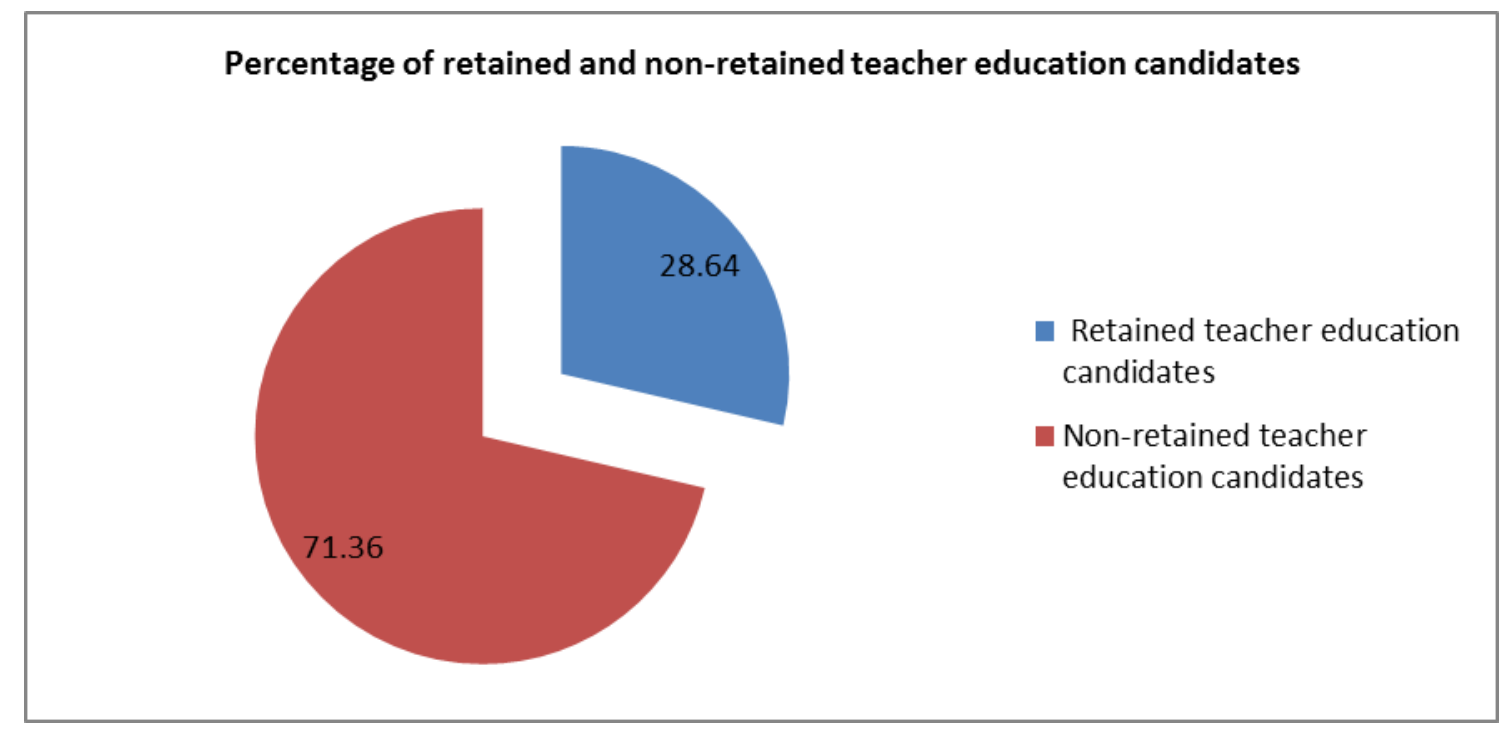

Figure 4: Chart showing the composite percentage of pre-service teachers' intention to enter the teaching profession

Figure 4 shows that $28.64 \%$ of the pre-service teachers polled are the ones who are likely to remain in the teaching profession while the remaining $71.36 \%$ are most likely not to enter the profession. The present evidence is a clear indication that there may be a sustained shortage in the supply of teachers who will drive the accomplishment of SDGs through education. Evidence and testimonies of increased registration of graduate teachers by the TRCN as adduced to the present registrar of the body, Professor Segun Ajiboye as obtained at the $2^{\text {nd }} \& 3^{\text {rd }}$ editions of teacher induction at the Obafemi Awolowo University, Ile-Ife, Nigeria held in 2017 and 2018 respectively and such other speaking engagements such as the $3^{\text {rd }}$ edition of the Education Convention organized by the Meadowhall group in 2019 , is no guarantee that the graduate teachers who are duly registered will enter and/or stay to make relatively signicant impact to the profession. Personal communication with some of the yet unemployed graduate teachers revealed that registration with TRCN was done on the basis of "should teaching become lucrative". Hence, issues on teacher quality and professionalism, attracting and motivating the best candidates to enter teacher education programs, the disparity in wages compared to other skilled workers, work conditions, etc. both at the private and public school systems need be attended to with all sense of direction and purpose.

\section{Conclusion}

The conclusion that may be reached from this study is that there may be an acute shortage of highly motivated teachers to drive the process of teaching people at all levels about and towards the accomplishment of SDGs. Attention should be given to this by stakeholders in education as much as there are postulations of suggestions on improvements in teacher preparation towards accomplishing these SDGs.

\section{References}

[1]. Adeleke, M. A., Adesina, B. A., Salami, M. O \& Adebayo, J. A. (2011). Influence of teaching practice exercise on accidental teacher education candidates at the Obafemi Awolowo University, Ile-Ife. Review of Higher Education in Africa 3 (1), 3-16.

[2]. Ajayi, S. O., \& Olatunji, O. A. (2017). Demographic analysis of turnover intentions amongst Nigerian high school teachers. Australian and International Journal of Rural Education, 27(1), 62-87.

[3]. Alabi, F. O. \& Ige, A. (2014). Issues in in-service education for teachers in Nigeria: The way forward in this decade and beyond. International Journal of Humanities, Social Sciences and Education 1 (12), 126132.

[4]. American Association of Colleges of Teacher Education (2010). $21^{\text {st }}$ century knowledge and skills in educator preparation. Being a paper produced as part of a collaborative project by the American Association of Colleges of Teacher Education and the Partnership for $21^{\text {st }}$ century skills (P21). 
[5]. Darling-Hammond, L., Burns, D., Campbell, C., Goodwin, A. L., \& Ling Low, E. (n.d). International Lessons in Teacher Education. Retrieved on $16^{\text {th }}$ May, 2018 from https://scale.stanford.edu/system/files/Teacher_Preparation_and_Teacher_Learning_A_Changing_Policy_ Landscape.pdf

[6]. Ehindero, O. J. (1994). The school and curriculum evolution in Nigeria. Ibadan, Nigeria: Textflow Limited.

[7]. Ehindero, S. (2014). Intellectual foundations of curriculum development, implementation and innovation. Ogun State, Nigeria: Melrose Publishing Company Limited.

[8]. Federal Ministry of Education (1992). National school curriculum review conference proceedings. Yaba, Lagos: Macmillan Nigeria Publishers Limited for Federal Ministry of Education.

[9]. Federal Ministry of Education (2016). Nigeria Education Indicators. Abuja, Nigeria: Author. Retrieved from http://www.memis. gov.ng on $2^{\text {nd }}$ June, 2018.

[10]. Federal Republic of Nigeria (2004). The national policy on education. Lagos: Nigerian Educational Research Development Council.

[11]. Federal Republic of Nigeria/International Labour Organisation (2005). Teachers for the future: Meeting teacher shortages to achieve Educational for All ( National Policy Brief). Nigeria: Authors.

[12]. Goldhaber, D. (2015). Excavating the teacher pipeline (and re-framing the discussion about the teacher shortage). Journal of Teacher Education July 8, 20140022487114542516.

[13]. Ingersoll, R. (2001). Teacher turnover, teacher shortages, and the organization of schools. Seattle, WA: University of Washington, Center for the Study of Teaching and Policy.

[14]. Nolan, F. (2016). Minnesota teacher crisis: How do we recruit and retain teachers we need to prepare the World's best workforce?. Author: Minnesota Rural Education Association.

[15]. Obanya, P. (2014). Repositioning Nigerian education on the world map: The role of National Examinations Council (NECO). Ibadan, Nigeria: Stirling-Horden Publishers Ltd.

[16]. Odia. L. O. \& Omofonmwan, S. I. (2007). Educational system in Nigeria: Problems and prospects. Journal of Social Science 14 (1), 81-86.

[17]. Tomlinson, C. A. (2010). Notes from an accidental teacher. Educational Leadership. US: ASCD. Retrieved from http://web.uvic.ca/ gtreloar/Articles/Opinion/Notes\%20from\%20an\%20Accidental\%20Teacher.pdf

[18]. Tiplic, D., Lejonberg, E., \& Elstad, E. (2016). Antecedents of newly qualified teachers' turnover intentions: Evidence from Sweden. International of Learning, Teaching and Educational Research 15 (5), 103-127.

[19]. Ukeje, O. \& Aisiku, J. U. (1982). Education in Nigeria. In A. Babs Fafunwa \& J. U. Aisiku (eds.) Education in Africa: A comparative survey. London, UK: George Allen \& Unwin (Publishers) Ltd.

[20]. Unterhalter, E., Ezegwu, C., Shercliff, E., Heslop, J., \& North, Amy (2015). Training teachers and gender equality in Nigeria: Reflections on measurement and policy. Paper presented at CIES annual conference, Washington D. C. retrieved from http://www.britishcouncil.org.ng on $2^{\text {nd }}$ June 2018.

[21]. Unterhalter, E., Jegede, P. O., Ezegwu, C., North, A. \& Shercliff, E. (2016). Teacher education, teacher practice, gender and girls' schooling outcomes- A study in five Nigerian States. Nigeria: Brtish Council

[22]. United Nations Educational, Scientific and Cultural Organisation (2017). Education for sustainable development goals- Learning objectives. Paris, France: Author.

[23]. Waititu, G.M. (2013). Analysis of factors influencing turnover intentions in public high schools in Limuru district, Kenya. Unpublished Masters of Business Administration dissertation, School of Business, Department of Business Administration, Kenyatta University.

[24]. Xaba, M. (2003). Managing teacher turnover. South African Journal of Education, 23 (4), $287-291$.

[25]. Zhao, H. \& Zhang, X. (2017). The influence of field teaching practice on pre-service teachers' professional identity: A mixed methods study. Frontiers in Psychology doi: 10.3389/fpsyg.2017.01264 